\title{
Bird populations in native forest patches in south-eastern Australia: the roles of patch width, matrix type (age) and matrix use
}

\author{
Dárius Pukenis Tubelis • \\ David B. Lindenmayer · Ann Cowling
}

Received: 24 November 2005 / Accepted: 21 February 2007/ Published online: 15 March 2007

(C) Springer Science+Business Media B.V. 2007

\begin{abstract}
We surveyed birds in patches of native eucalypt forest and in surrounding exotic matrix (Radiata pine forests) in south-eastern Australia. Our objectives were: (1) to examine the influence of the width of native forest patches and the age of surrounding pine forests on bird occurrence in patches of native forest; and (2) to verify the relationship between the use of the surrounding pine matrix and bird species response to variation in width of patches of native forests. A total of 32 study sites (boundaries between eucalypt and pine forests) were surveyed. Birds were counted by the area search method within 0.5 -ha quadrats. Data were analysed using generalised linear models. Wide patches of eucalypt forest supported higher species richness and greater numbers of birds, such as foliage searchers and
\end{abstract}

D. P. Tubelis · D. B. Lindenmayer

Centre for Resource and Environmental Studies,

The Australian National University, Canberra,

ACT 0200, Australia

A. Cowling

Statistical Consulting Unit, The Australian National

University, Canberra, ACT 0200, Australia

Present Address:

D. P. Tubelis $(\bowtie)$

Department of Ecology, Institute of Biosciences,

University of São Paulo, Matão street, no 321,

Sao Paulo, SP 05508-900, Brazil

e-mail: dtubelis@yahoo.com nectarivores, than narrow patches. Matrix age also influenced the occurrence of some species in native patches. The abundance of species in wide and narrow patches of native forest was related to their use of the matrix. This was true for native forests surrounded by old but not by young pine forests. We suggest that management in wood production landscapes take into account both characteristics of native patches and the surrounding matrix. Negative impacts of fragmentation in managed landscapes might be reduced by promoting matrix types that are suitable for bird species.

Keywords Bird species - Forest management . Habitat edge - Habitat juxtaposition - Landscape matrix $\cdot$ Patch $\cdot$ Patch width $\cdot$ Vegetation boundary

\section{Introduction}

Bird occurrence in patchy environments can be influenced by a diverse range of factors (Cody 1985; Keast et al. 1985; Wiens 1989; Bibby et al. 1992; Ford et al. 2001). Patch attributes such as vegetation structure (Kikkawa 1982; Recher et al. 1991), floristic composition (MacNally 1990), topographic position (Catterall et al. 2001) and the presence of important resources like food (Zanette et al. 2000) can contribute substantially 
to the occurrence of bird species in habitat patches. Similarly, dimensional attributes of patches, such as their width, have been recognised as important factors correlated with bird species occurrence within vegetation patches in landscape mosaics (Recher et al. 1987; Darveau et al. 1995; Bentley and Catterall 1997; Hagar 1999; Lambert and Hannon 2000; Sieving et al. 2000; Pearson and Manuwal 2001; Hannon et al. 2002; Shirley and Smith 2005).

The surrounding vegetation also can contribute to variation in bird numbers in habitat patches in several ways. For example, the total amount of cover of native vegetation in landscapes can influence bird occurrence in native patches (Andrén 1994; Price et al. 1999; Lee et al. 2002). Also, the surrounding vegetation can influence the composition of communities inhabiting patches by adding species, which tend to be more numerous at edges than in interiors of these patches (Brittingham and Temple 1983; Møller 1989; Tubelis et al. 2004a). Further, adjacent vegetation might cause negative edge effects, thus leading to relatively reduced abundances of some species at edges of native patches compared with interior areas (Restrepo and Gómez 1998; Piper and Catterall 2003; Laurance 2004). The fact that species able to use the surrounding matrix tend to be more tolerant of habitat fragmentation than species that do not use the matrix has been recognised for diverse groups such as mammals (Laurance 1990, 1991), birds (Stouffer and Bierregaard 1995; Bierregaard and Stouffer 1997; Warburton 1997; Renjifo 2001; Antongiovanni and Metzger 2005) and insects (Ricketts 2001).

This study was conducted in an exotic Radiata Pine (Pinus radiata) plantation (termed here as "the matrix") containing patches of remnant native forest, at Tumut, south-eastern Australia. Our first hypothesis was that patch width would influence bird occurrence (total bird species richness, total bird abundance, abundance of most guilds and species) in patches of native eucalypt forest, as has been found elsewhere (e.g. Sieving et al. 2000; Hannon et al. 2002). Wide eucalypt patches would support more species and higher populations of birds typical of these eucalypt forests; which originally occupied extensive continuous areas in this region.
Our second hypothesis was that the age of surrounding pine forest would influence bird occurrence in native eucalypt forests. Specifically, native patches surrounded by old pine forests would support greater bird abundance, higher species richness, and more individuals of most species and guilds than those patches surrounded by young pine forests. This would occur for two reasons. First, old pine forests might provide a more suitable foraging area for birds living in native patches because their structure is similar to that of native forests (see Tubelis et al. 2004b). Second, the structure of old pine forests might lead to reduced edge effects that influence bird occurrence in native patches, in comparison to young pine forests. This is because negative impacts of edges are usually more intense at boundaries marked by high contrast between the vegetation structure of the matrix and the remnant/patch (DeGraaf 1992; Sisk et al. 1997; Luck et al. 1999).

Our third hypothesis was that greater reduction in abundance in response to a decrease in width of eucalypt patches would tend to be shown by bird species that make lesser use of the surrounding matrix (pine forest). We expected this to occur because, by using surrounding pine forests, bird species could compensate for the decrease in width of native forest by foraging in the surrounding pine forest. Accordingly, species not able to use the matrix would tend to be more abundant in wide than narrow patches of native forests. We discuss the results of our tests of the three hypotheses in terms of potential conservation strategies in plantation-dominated landscapes.

\section{Methods}

Study area

The study was conducted in the Tumut region of southern New South Wales, in south-eastern Australia. An exotic plantation, primarily of Radiata Pine, occupies a considerable part (60,000 ha) of the landscape, which was originally dominated by native eucalypt forest but then cleared for plantation establishment. This matrix 
of pine forest contains remnants of the original eucalypt forest cover-riparian strips connected to the extensive forest bordering the plantation. Rotation periods of about 30-32 years have led to the occurrence of pine stands of different ages, as well as clearcuts. Farm dams and areas of farmland are also features of this landscape. Additional information on this region can be found in Lindenmayer et al. (2002).

\section{Study sites}

A total of 32 study sites (boundaries between eucalypt and pine forests) was selected for study. The selected study sites were usually separated by at least $1 \mathrm{~km}$ to increase the probability of abundances being independent at different sites. Four types of boundaries, with eight replicates of each, were studied. They differed in relation to two factors: the width of native forests and the age of the surrounding exotic plantation (Appendix 1).

Native eucalypt forests measuring between $50 \mathrm{~m}$ and $110 \mathrm{~m}$ in width were classified as narrow patches, while those measuring more than $300 \mathrm{~m}$ in width were classified as wide patches. Only forests dominated by Narrow-leaved Peppermint (Eucalyptus radiata) and Ribbon Gum (E. viminalis) were selected to control for the effects of forest type on bird assemblages. Also, native forest disturbed by cattle trampling or other factors were not sampled to avoid confounding effects. All stands of native forest were multiaged with many trees of different cohorts reflecting the typical non-stand replacing disturbance dynamics of eucalypt forest in this region (Specht and Specht 1999).

Old pine plantations comprised exotic forests aged between 20 and 30 years, while young pine plantations comprised pine plantations aged between 4 and 15 years. These two classes of exotic plantations differed markedly in structure. The old stands have a lower density of pine trees, as they had been subjected to one more thinning operation than the young stands (see Lindenmayer et al. 2002). As the growth rate of these pine trees is about a meter per year, trees also were larger than in young stands (Gepp 1976). The vegetation within each pine stand was homogeneous, as pine trees were of the same age and were equally spaced. Also, second-growth and remnant native trees and shrubs were scattered in the pine plantations, being homogeneous within a stand, and more numerous in older stands (see Tubelis et al. 2004b).

\section{Bird surveys}

Eight quadrats (each measuring $50 \mathrm{~m}$ by $100 \mathrm{~m}$ ) were set out at each study site, four in the eucalypt forest and four in the pine forest (Fig. 1). These 0.5-ha quadrats were established with their longest axes parallel to and $0-50 \mathrm{~m}$ from the boundary line (an unsealed road measuring about $7 \mathrm{~m}$ in width). We adopted this sampling scheme to record bird species that occur adjacent to a boundary between native and exotic forests.

Surveys were conducted between early October and late December 2001, which corresponded to the breeding period of most forest bird species in this region (Lindenmayer et al. 2002). To avoid confounding seasonal variation and treatment, the four types of boundaries were surveyed

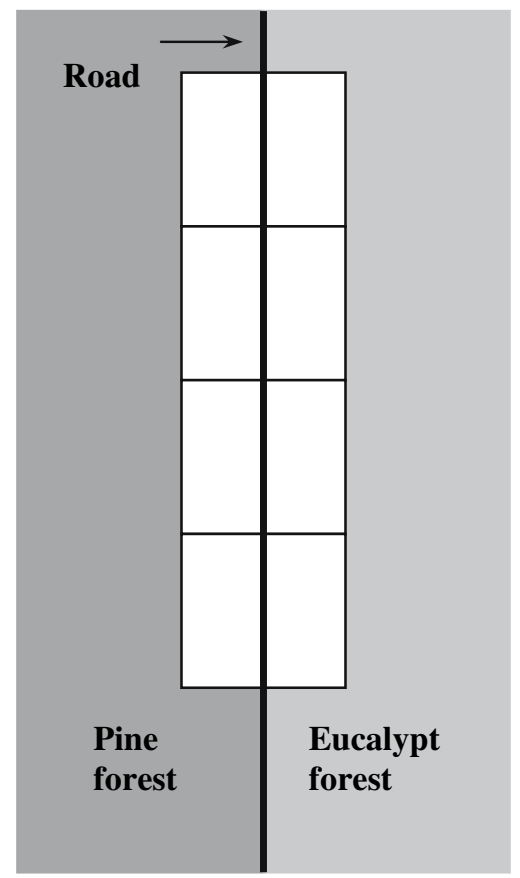

Fig. 1 Diagram showing a grid of eight quadrats established in one study site. A road measuring $7 \mathrm{~m}$ in width separated the pine and eucalypt forests. Each quadrat measured $100 \mathrm{~m}$ by $50 \mathrm{~m}$ 
alternatively with further replicates of each treatment being surveyed only after all boundary types had the same number of replicates completed.

Each sample consisted of walking a quadrat (area search method) during seven minutes and recording all birds heard or seen within the limits of the quadrat. Birds flying over the forests and those outside the quadrat were not recorded. All the quadrats at a site were sampled on the same morning, between sunrise and 9:30 h. After a given sample was collected, the observer (D.P.T.) walked to another quadrat at least $50 \mathrm{~m}$ from the previously surveyed quadrat. Walking along such narrow quadrats permitted the observer to hear and see most birds recorded. Thus, we consider that the detectability of species at all sites is comparable. In a given morning, each bird in each quadrat was counted only once, thus avoiding problems with pseudo-replication. Bird species classification in trophic guilds followed MacNally (1994).

\section{Statistical methods}

\section{Bird occurrence in patches of eucalypt forest}

We analysed the effect of the width of the eucalypt forest ("width") and of the age of the surrounding pine plantation ("age") on bird occurrence in patches of native eucalypt forest. Analyses used only the data from the four quadrats in the eucalypt forest at each of the 32 study sites. A range of response variables was examined as shown below.

For the overall analyses:

the total number of species detected at each patch (species richness)

the total number of guilds detected at each patch (guild richness)

the total number of individuals detected at each patch (bird abundance)

Analyses for each guild included:

the total number of individuals (abundance) of the guild detected at each patch

the proportion of quadrats at each patch on which the guild was detected
Analyses of most frequently detected species included:

the total number of individuals (abundance) of the species detected at each patch

the proportion of quadrats at each patch on which the species was detected

The most frequently recorded bird species were determined on the basis of both the number of quadrats and number of patches at which they were detected. In the analyses, we used the 11 species detected on both more than $10 \%$ (13 or more) of the quadrats and at least half the sites (16 or more). We applied the same cutoff point to the guilds (and therefore one of the guilds-the ground carnivores, was not included in the analyses).

We used Generalised Linear Models (GLMs) for all analyses with age, width and their interaction as fixed effects. We used Poisson models when the response was the number of species, guilds or individuals, and binomial models when the response was the proportion of quadrats at a site. In most cases, the model was overdispersed. Overdispersion was estimated and used to adjust the test variables. Statistical analyses were performed in Genstat (2003). Graphs were produced using S-PLUS (2003).

\section{Relationship between occurrence in eucalypt and pine forests}

These analyses used data from all eight quadrats at each of the 32 sites. To test relationships between matrix use and response to variation in patch width by species, we adopted the following procedures. First, the data were divided into two groups: data from boundaries with old pine forest and data from boundaries with young pine forest. Analyses were performed separately for each group. Then, the species that occurred in at least five quadrats were selected. This selection was done to avoid dealing with species rarely recorded-thus reducing the probability of making equivocal decisions about habitat use by these species. Then, for each species, two measures of habitat use were calculated: 
- Use of wide and narrow patches of native forest $(R)$

This was calculated as $R=W /(N+W)$, with $W=$ total number of birds of a species recorded in quadrats in wide eucalypt forest and $N=$ total number of birds of a species recorded in quadrats in narrow eucalypt forest.

Values of this measure lie between 0 and 1 . Values close to 1 are characteristic of species that are more numerous in wide patches, while values close to 0 indicate species that are more numerous in narrow patches of native eucalypt forest. Species with values around 0.5 occur similarly in narrow and wide patches.

- Matrix use $(M)$

This was calculated as $M=P /(E+P)$, with $P=$ total number of birds of a species recorded in quadrats in the pine forest and $E=$ total number of birds of a species recorded in quadrats in the eucalypt forest.

Values of this measure also lie between 0 and 1. Values above 0.5 indicate higher proportion of individuals found in the pine matrix, while those values below 0.5 indicate higher proportion of birds in the eucalypt forest.

\section{Results}

Overview of bird occurrence in eucalypt forest

Altogether 43 species and 1,508 individual birds were recorded in the 128 quadrats in the eucalypt forest. Wide patches of eucalypt forest surrounded by old pine forest had the highest total number of individuals recorded. The highest total numbers of species were recorded in wide eucalypt forest (Appendix 1). There was an effect of the width of the eucalypt forest on both the number of species and the total number of birds, but not the number of guilds recorded per patch of eucalypt forest (Table 1). More bird species per patch (14.8 vs. 11.3) and more individuals per patch (53.4 vs. 40.9) were recorded in wide than in narrow eucalypt forests. The age of the surrounding pine forest and the interaction between age and width did not have a significant effect on bird abundance, species richness, or on the number of guilds detected per patch of eucalypt forest (Table 1).

Guilds in eucalypt forest

The effect sizes of patch width and matrix type, and of their interaction, on the occurrence of different guilds in patches of native forest are shown in Fig. 2. The effect of width on individuals of a guild detected at each patch was statistically significant for foliage searchers and nectarivores. Results were very similar for the proportion of quadrats in each patch at which each guild was detected. These two guilds tended to be more abundant and more frequent in wide rather than narrow patches of native forests. Other guilds tended to be ubiquitous in relation to the width of native forests (Fig. 2).

The age of the surrounding matrix had a significant effect on the occurrence of pouncers

Table 1 Influence of the width of native eucalypt forest and the age of the surrounding pine matrix on the number of species, total number of birds and the number of guilds recorded per site $(n=32)$ in eucalypt forests at Tumut, NSW, Australia

\begin{tabular}{llccrr}
\hline Response & Effect & Estimate & SE & $t(28)$ & $P$-value \\
\hline Number of birds & Age Y & -0.018 & 0.158 & -0.12 & 0.909 \\
& Width W & 0.414 & 0.144 & 0.88 & -1.52 \\
Number of species & Age*Width & -0.322 & -212 & -0.65 & 0.140 \\
& Age Y & -0.055 & 0.085 & 0.520 \\
Number of guilds & Width W & 0.263 & 0.113 & 0.04 & 0.002 \\
& Age*Width & 0.004 & 0.074 & 0.969 \\
& Age Y & -0.116 & 0.072 & 0.00 & 0.131 \\
& Width W & 0.000 & 0.017 & 0.17 & 0.870 \\
\hline
\end{tabular}

The Age effect is the effect of young pine forest relative to old pine forest. The Width effect is the effect of wide eucalypt forest relative to narrow eucalypt forest 
Fig. 2 Effects and associated $95 \%$ confidence intervals for the age of surrounding pine matrix (A), width of native eucalypt forest $(\mathrm{W})$ and their interaction $(\mathrm{A} * \mathrm{~W})$ on the number of individuals of a guild (left panel) and the proportion of quadrats on which that guild was observed (right panel) in eucalypt forests at Tumut, south-eastern Australia. The Age effect is the effect of young pine forest relative to old pine forest. The Width effect is the effect of wide eucalypt forest relative to narrow eucalypt forest. Because foliage searchers were seen on all but three quadrats, results concerning proportion of quadrats are not of interest
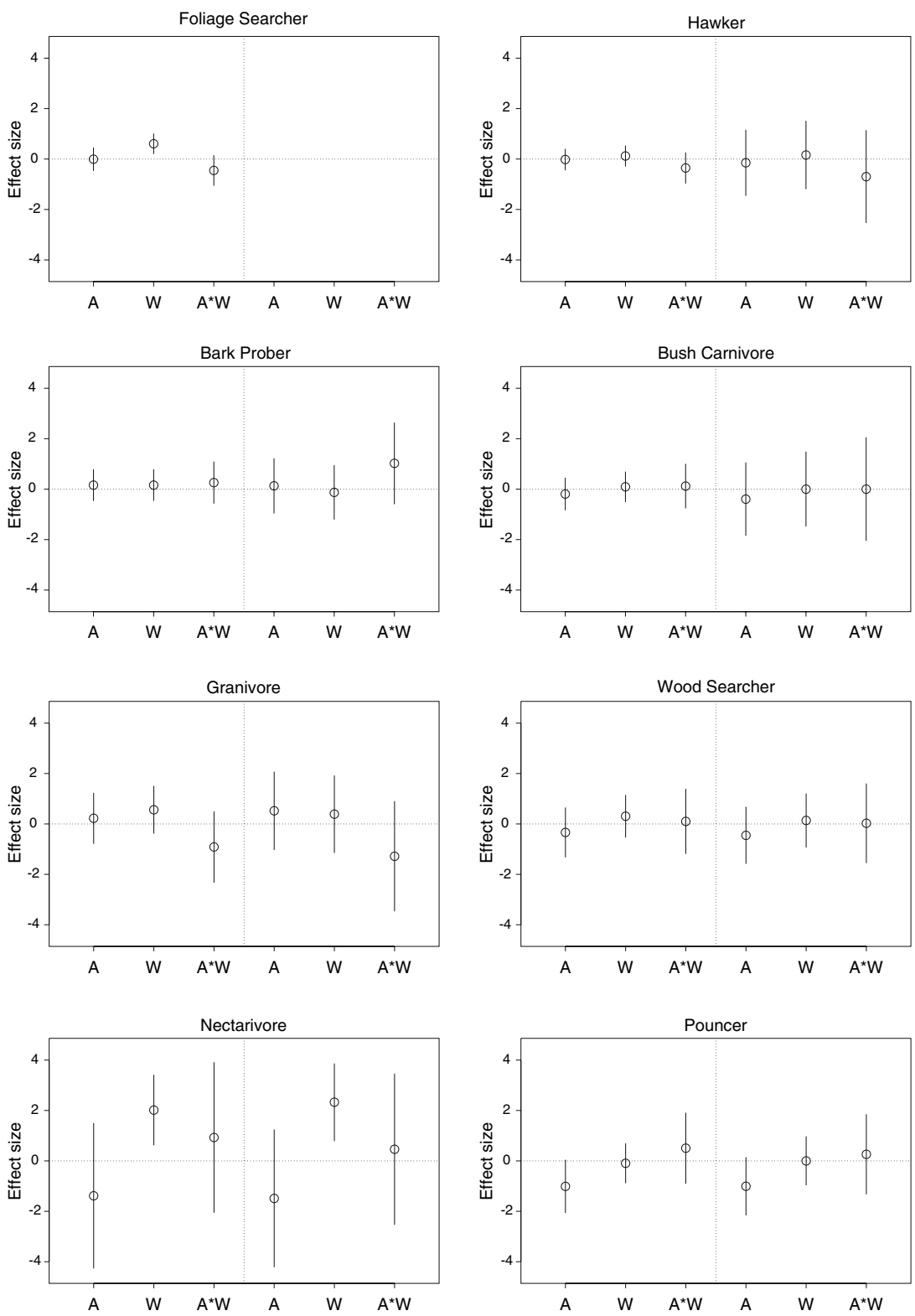

in native patches. Members of this guild were more abundant and more frequently detected in patches surrounded by old rather than young pine forest. Other guilds were ubiquitous in relation to the age of the adjacent matrix, although nectarivores also showed a similar but weak tendency to that of pouncers (Fig. 2).

The interaction between patch width and matrix age weakly influenced the occurrence of three guilds-foliage searchers, hawkers and granivores-in the native patches (Fig. 2). For these guilds, the influence of age of adjacent pine forest depended on the width of native patches (Appendix 1). The effects of the interaction were somewhat weaker for the other guilds (Fig. 2).

Species in eucalypt forest

Patch width, matrix age and their interaction significantly influenced the occurrence of several species in patches of eucalypt forest (Fig. 3). The effects of patch width on species occurrence in 
these native patches were more substantial for Anthochaera carunculata, Lichenostomus chrysops and Strepera graculina. They were more numerous and were more frequently detected in wide rather than narrow patches of eucalypt forest (Fig. 3). Most of the other species analysed were ubiquitous in relation to the width of native forests.
The age of adjacent pine forest had strong effects on the occurrence of Lichenostomus chrysops and Strepera graculina. These species were more numerous and more frequently detected in native patches surrounded by old rather than young pine forests. Other analysed species showed weaker responses or were ubiquitous in relation to matrix age (Fig. 3). The interaction
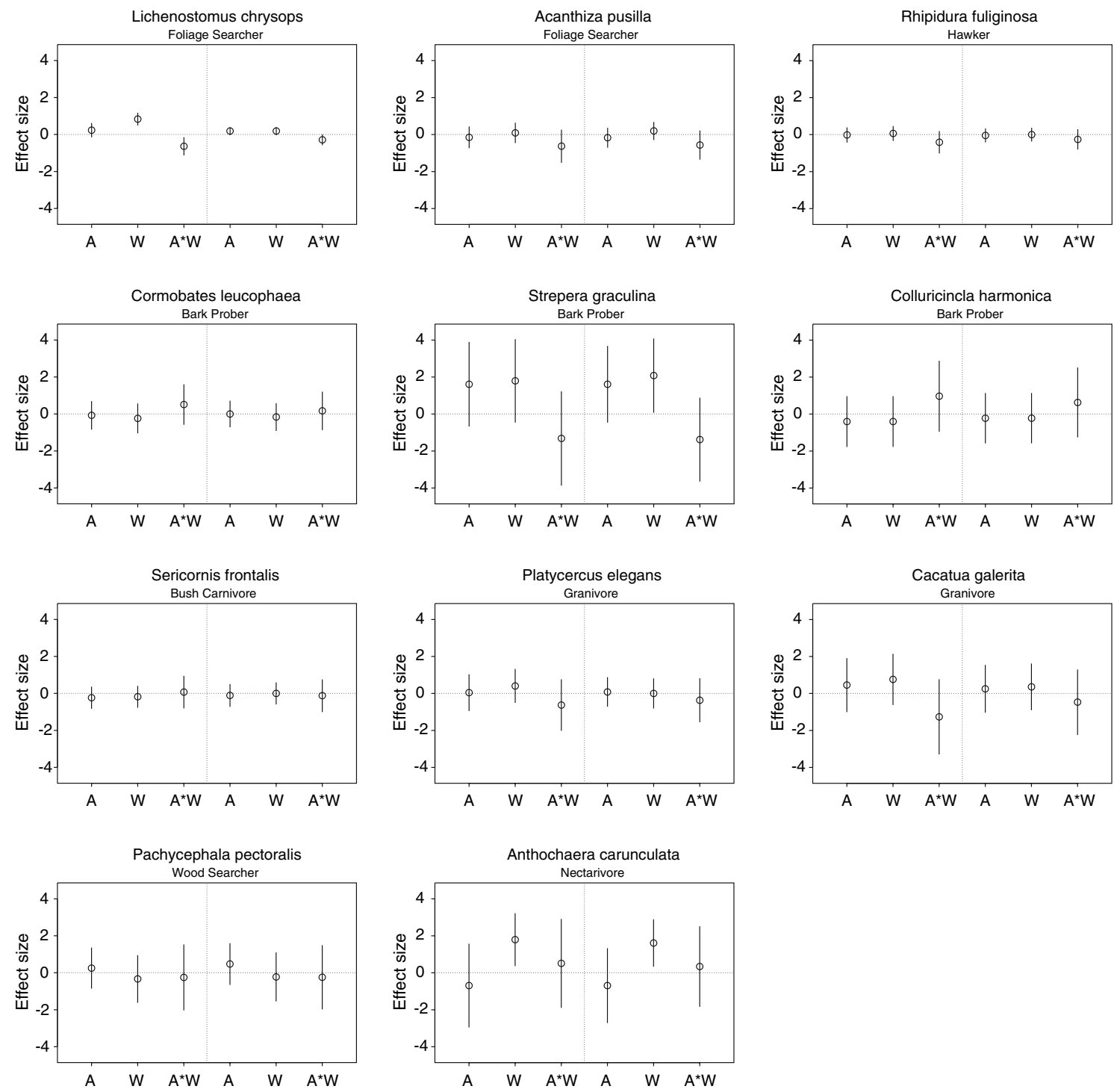

Fig. 3 Effects and associated $95 \%$ confidence intervals for the age of surrounding pine matrix (A), width of native eucalypt forest $(\mathrm{W})$ and their interaction $(\mathrm{A} * \mathrm{~W})$ on the number of individuals of a species (left panel) and the proportion of quadrats on which that species was observed (right panel) in eucalypt forests at Tumut, south-eastern Australia. The Age effect is the effect of young pine forest relative to old pine forest. The Width effect is the effect of wide eucalypt forest relative to narrow eucalypt forest 
between age and width was more substantial on the occurrence of Lichenostomus chrysops.

Relationship between matrix use and occurrence in wide and narrow patches

The relationship between matrix use and occurrence in wide patches (Fig. 4) revealed major patterns of habitat use by the more abundant species at boundaries between native and exotic forest. First, bird species tended to be more abundant in native eucalypt forest than in exotic pine forest, as there were just two species with values of matrix use higher than 0.5 . Second, the age of the surrounding pine forest influenced the occurrence in wide and narrow patches of native forest by species. This was because the number of species with values higher or lower than 0.5 were 13 and 6, respectively, in boundaries with old pine forest, whereas the respective values were 8 and 8 at boundaries with young pine forest (Fig. 4). Thus, a higher proportion of bird species tended to be more abundant in wide than in narrow patches of eucalypt forest when surrounded by old rather than by young pine forest. Third, bird species with a tendency to occur in wide patches of eucalypt forest (higher values on $\mathrm{Y}$ axes) tended to be those that made lower use of

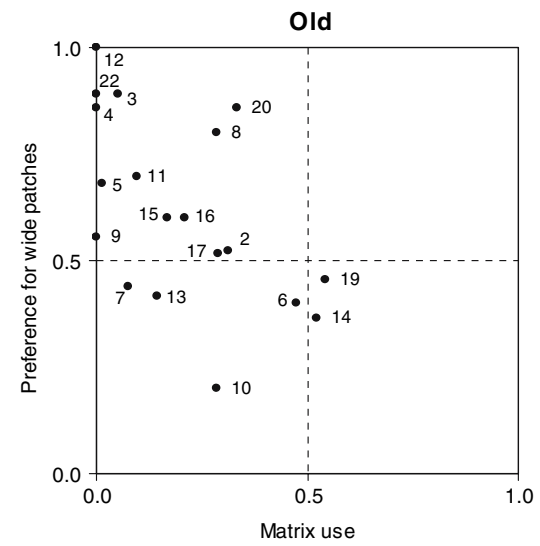

Fig. 4 Relation between matrix use and tendency to occur in wide patches by bird species in boundaries between exotic pine forest (matrix) and native eucalypt forest at Tumut, south-eastern Australia. Data are presented for boundaries with old and young pine forest. See methods for details on these two measures of habitat use. Codes for species-1: Acanthiza lineata; 2: Acanthiza pusilla; 3: Acanthorhynchus tenuirostris, 4: Anthochaera carunculata; surrounding pine forest (lower values on $\mathrm{X}$ axes). Species with a tendency to be more numerous in narrow patches tended to make more use of the surrounding pine forest. This effect was stronger for boundaries with old pine forest because the correlation between the two measures of habitat use was higher at boundaries with old $(r=-0.56$; $P=0.013)$ than with young $(r=-0.31 ; P=0.246)$ pine forest. Species such as Melithreptus lunatus, Zosterops lateralis, Acanthorhynchus tenuirostris and Anthochaera carunculata tended not to use the pine matrix, and were more numerous in wide than in narrow patches of eucalypt forest (Fig. 4). On the other hand, species such as Acanthiza pusilla, Colluricincla harmonica, Eopsaltria australis, Rhipidura fuliginosa and Sericornis frontalis made greater use of the surrounding matrix and were more abundant in narrow than wide patches of native forest, or were ubiquitous in relation to patch width (Fig. 4).

\section{Discussion}

Influence of patch width

Wide patches had significantly higher species richness, greater bird abundance, and supported

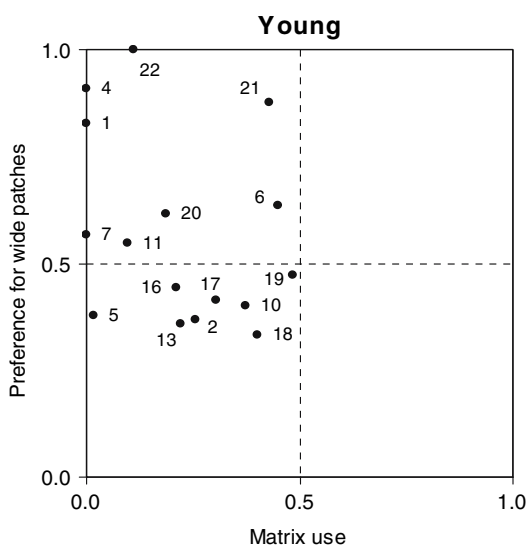

5: Cacatua galerita; 6: Colluricincla harmonica; 7: Cormobates leucophaea; 8: Cuculus flabelliformis; 9: Dacelo novaeguineae; 10: Eopsaltria australis; 11: Lichenostomus chrysops; 12: Melithreptus lunatus; 13: Pachycephala pectoralis; 14: Pachycephala rufiventris; 15: Pardalotus punctatus; 16: Platycercus elegans; 17: Rhipidura fuliginosa; 18: Rhipidura rufifrons; 19: Sericornis frontalis; 20: Strepera graculina; 21: Zoothera lunulata; 22: Zosterops lateralis 
more individuals of several species and guilds than narrow patches of native forest-a result in agreement with our first hypothesis. Similar influences of patch width on bird occurrence in native forests has been reported in other ecosystems (Stauffer and Best 1980; Recher et al. 1987; Darveau et al. 1995; Bentley and Catterall 1997; Kilgo et al. 1998; Hagar 1999; Sieving et al. 2000; Hannon et al. 2002; Shirley and Smith 2005).

Narrower patches of eucalypt forest might be less suitable for some species than wider patches due to three major factors. First, some birds might face difficulties in establishing home ranges in narrow patches of eucalypt forest. If not able to exploit resources in the surrounding pine forests, birds living in narrow forests would need to have long and narrow territories, which might make it difficult for nest protection, territory defence and foraging efficiency (Pyke et al. 1977; Recher et al. 1987). Second, as several species in the studied landscape are sensitive to the area of native forest patches (Lindenmayer et al. 2002), narrow patches might not be compatible with the area requirements of some species of birds. Third, as bird species might respond negatively to adjacent habitats (Luck et al. 1999; Laurance 2004), some bird species might not have found appropriate ("interior") habitat in narrow patches.

Not all species in a guild showed similar responses to patch width. For example, Zosterops lateralis was more numerous in wide rather than narrow patches, while Sericornis frontalis was more numerous in narrow rather than wide patches of native forest (Appendix 1). Such inter-specific variation was a factor contributing to reduce the effect sizes of patch width on the occurrence of different guilds in patches of native forest. Another factor to be considered is that the abundance of some guilds and particular species in wide and narrow patches of native eucalypt forest was influenced by the age of pine forest.

Foliage searchers and nectarivores were the guilds most affected by variation in width of patches of eucalypt forest. Species such as $\mathrm{Me}$ lithreptus lunatus and Lichenostomus chrysops (foliage searchers), Acanthorhynchus tenuirostris and Anthochaera carunculata (nectarivores) and species of other guilds, such as Strepera graculina (bark prober), Zosterops lateralis (bush carnivore) and Cuculus flabelliformes (pouncer) probably require plant resources and an associated fauna that likely occur in lower abundances in narrow than wide patches of native forest. These guilds and species might suffer population declines if native forests occur only as narrow strips in this region.

We cannot propose a minimum width for forest conservation in this landscape as it would require surveying birds in several classes of eucalypt patch width (e.g. Hannon et al. 2002). However, our study highlights the possibility that current forestry prescriptions protecting $20 \mathrm{~m}$ of eucalypt forest along each side of creeks in this Australian region might not effectively protect some species. This is because the $40 \mathrm{~m}$ wide eucalypt forests protected by current prescriptions are narrower than the forests considered as narrow (50-100 m wide) in our study.

Influence of the surrounding matrix

The age of pine forest surrounding the eucalypt patches tended not to affect the abundance of most species or guilds. As a consequence, species richness and total bird abundance found per patch also were not significantly affected by the age of the adjacent matrix. Thus, the support for our second hypothesis was weak. This lack of an influence of matrix type on bird occurrence in native patches might be the result of two factors. For these species, native forests might be much more valuable as habitat than adjacent exotic pine forests. Thus, the age of the pine forest has little influence on their populations in native patches. Also, young and old pine forests might lead to comparable edge effects on the populations of these species in native patches.

Only pouncers (especially Dacelo novaeguinae) as well as a few other species of other guilds (e.g. Acanthiza pusilla, Acanthorhynchus tenuirostris and Melithreptus lunatus) were more abundant in patches surrounded by old than by young pine matrix, thus supporting our second hypothesis. This result is similar to reports of matrix influence on wildlife occurrence in fragments of native vegetation in other landscapes (Sisk et al. 1997; Gascon et al. 1999; Ricketts 2001). Matrix types considered as more appropriate 
for bird conservation usually have been those with vegetation structure similar to that of native vegetation fragments or patches (Stouffer and Bierregaard 1995; Estades and Temple 1999; Renjifo 2001; Wethered and Lawes 2003; Antongiovanni and Metzger 2005). Accordingly, at Tumut, older pine forests supported higher numbers of the species mentioned above than young pine forests.

Patterns of occurrence of foliage searchers (especially Lichenostomus chrysops) revealed that the influence of matrix type can vary with the width of native patches. For wide patches, higher bird abundance in native forests surrounded by old than by young pines might be the result of a greater suitability of old stands as a buffer against edge effects (Wilcove et al. 1986), particularly through providing additional foraging areas. On the other hand, there were fewer birds in narrow patches surrounded by old matrix than in narrow patches adjacent to young pines suggesting that other factors might be involved in the influence of matrix age on bird populations in the eucalypt remnants. Likely, biotic and abiotic edge effects and species interactions might be involved. Interactions between matrix type and patch dimensions have not been reported in previous studies investigating the role of matrix on patch occupation by wildlife (see Stouffer and Bierregaard 1995; Sisk et al. 1997; Estades and Temple 1999; Gascon et al. 1999; Ricketts 2001; Renjifo 2001; Wethered and Lawes 2003).

\section{Matrix use and sensitivity to patch width}

Relationships between the two measures of habitat use by the more abundant species supported our third hypothesis-more dramatic responses to a decrease in width of eucalypt patches would tend to be shown by species that make lesser use of the matrix. For example, Melithreptus lunatus and Acanthorhynchus tenuirostris made little use of the adjacent matrix, and were more abundant in wide than in narrow native patches. Conversely, Acanthiza pusilla and Rhipidura fuliginosa were among species that made greater use of the matrix and tended to be more numerous in narrow than wide patches of native forest. This general pattern is in agreement with other work that has shown that matrix use by wildlife can be a major factor influencing their sensitivity to habitat fragmentation (Laurance and Bierregaard 1997; Gascon et al. 1999; Lindenmayer et al. 2003).

For birds, it was suggested that this relationship occurs because of the role of the matrix in influencing inter-patch movements (Stouffer and Bierregaard 1995; Renjifo 2001; Sekercioglu et al. 2002; Wethered and Lawes 2003) and in providing additional foraging area for different species (Estades and Temple 1999; Renjifo 2001). These two factors may underpin the patterns observed in our study area. We consider that bird occurrence in the pine matrix was related mostly to matrix use as additional foraging areas, as we often noted birds foraging within pine forest and then returning to the native forest. Birds found in the pine forest were unlikely to be using the matrix as a pathway to reach other patches of native forest. This was because the surveyed portions of pine forest were adjacent to the surveyed eucalypt forest and distant (usually $>800 \mathrm{~m}$ ) from the other areas of eucalypt forests. Although the bird species recorded in our sites of eucalypt patches might be able to move such distances, these distances are larger than typical territory diameters. In addition, most birds seen leaving the eucalypt patches used the matrix as additional foraging areas.

The correlation between matrix use and the tendency to occur in wide patches was higher when the sampling sites were within old than young pine forests. Thus, matrix attributes can influence such relationships. We consider that these differences occurred mainly due to the suitability of pine forests as foraging places for birds. In a previous study, we found evidence that birds inhabiting native patches can compensate for negative aspects of patch dimensions by foraging in adjacent pine forest (Tubelis et al. 2004b).

The analyses examining the effects sizes of patch width and matrix type on bird occurrence in native patches (Figs. 2, 3) showed weak evidence for a substantial influence of matrix age on most species and guilds. However, examination of the relationship between matrix use and sensitivity to patch width (Fig. 4) permitted an overall 
comparison of the responses of the more abundant species to landscape change in the study area. Thus, comparing component-species of communities inhabiting boundaries with old and young pine forests revealed an effect of matrix age not shown by individual comparisons of species occurrence in native patches.

\section{Implications for forest management}

Bird conservation might be improved with the retention of wide rather than narrow patches of eucalypt forest within Radiata Pine plantations. Because small native patches also can have considerable conservation value (Lindenmayer et al. 2002), narrow patches should not be cleared even though they have lower value for birds than wide patches.

In general, the occurrence of bird species in native eucalypt forests tended to be more influenced by patch width than by the type of surrounding pine matrix. Thus, conservation efforts in this wood production landscape should consider attributes of native patches and pine matrix as of primary and secondary concern, respectively.

The influence of matrix type on the sensitivity of bird species to variation in patch width (Fig. 4) suggests that the matrix can have a major role in determining remnant occupation in fragmented landscapes. This study suggests that the role of native patches in the conservation of bird species can be improved by promoting the existence of more suitable matrix types surrounding remnants. In the study area, maintenance of bands of old pine forest adjacent to patches of native eucalypt forest would likely benefit several species inhabiting such native patches.

Acknowledgements We thank State Forests of New South Wales for providing field facilities. C. MacGregor and M. Pope provided important assistance during the early phases of this study. R. Cunningham made suggestions on the experimental design during the planning of field surveys. C. P. Catterall, S. J. Hannon, S. G. W. Laurance, H. A. Nix and D. Saunders improved this manuscript with very constructive suggestions. The field work was financed by grants from CRES, CSIRO and David B. Lindenmayer. D. P. Tubelis's PhD study at CRES was supported by a scholarship (No. 200102-00/1) from the Brazilian Council for Science and Technology (CNPq). The writing process of this manuscript was supported by FAPESP (No. 05/03466-4).

\section{Appendix 1}

Number of individuals of bird species found in narrow and wide patches of eucalypt forest, surrounded by old and young pine forest matrix, at Tumut, south-eastern, Australia. Classification on guilds followed MacNally (1994).

\begin{tabular}{|c|c|c|c|c|c|}
\hline \multirow[t]{2}{*}{ Species } & \multirow[t]{2}{*}{ Guild } & \multicolumn{2}{|c|}{ Young matrix } & \multicolumn{2}{|c|}{ Old matrix } \\
\hline & & Narrow & Wide & Narrow & Wide \\
\hline Rhipidura fuliginosa & hawker & 47 & 33 & 48 & 51 \\
\hline Myiagra rubecula & hawker & 0 & 4 & 0 & 3 \\
\hline Eopsaltria australis & pouncer & 3 & 2 & 4 & 1 \\
\hline Cuculus flabelliformis & pouncer & 0 & 2 & 1 & 4 \\
\hline Dacelo novaeguineae & pouncer & 0 & 2 & 4 & 5 \\
\hline Todiramphus sanctus & pouncer & 0 & 0 & 1 & 0 \\
\hline Petroica multicolor & pouncer & 1 & 0 & 1 & 0 \\
\hline Psophodes olivaceus & ground carnivore & 8 & 0 & 6 & 0 \\
\hline Menura novaehollandiae & ground carnivore & 2 & 0 & 0 & 0 \\
\hline Corcorax melanorhamphos & ground carnivore & 8 & 6 & 10 & 5 \\
\hline Rhipidura rufifrons & bush carnivore & 4 & 2 & 1 & 0 \\
\hline Zosterops lateralis & bush carnivore & 0 & 16 & 2 & 16 \\
\hline Sericornis frontalis & bush carnivore & 38 & 34 & 48 & 40 \\
\hline Falcunculus frontatus & bark prober & 0 & 1 & 1 & 0 \\
\hline Colluricincla harmonica & bark prober & 4 & 7 & 6 & 4 \\
\hline
\end{tabular}


Appendix 1 continued

\begin{tabular}{|c|c|c|c|c|c|}
\hline \multirow[t]{2}{*}{ Species } & \multirow[t]{2}{*}{ Guild } & \multicolumn{2}{|c|}{ Young matrix } & \multicolumn{2}{|c|}{ Old matrix } \\
\hline & & Narrow & Wide & Narrow & Wide \\
\hline Strepera graculina & bark prober & 10 & 16 & 2 & 12 \\
\hline Cormobates leucophaea & bark prober & 13 & 17 & 14 & 11 \\
\hline Coracina novaehollandiae & wood searcher & 0 & 2 & 0 & 4 \\
\hline Phylidonyris pyrrhoptera & wood searcher & 0 & 1 & 0 & 0 \\
\hline Pachycephala pectoralis & wood searcher & 9 & 5 & 7 & 5 \\
\hline Petroica rosea & wood searcher & 0 & 2 & 0 & 2 \\
\hline Pachycephala rufiventris & wood searcher & 0 & 3 & 7 & 4 \\
\hline Lichenostomus leucotis & wood searcher & 1 & 2 & 0 & 4 \\
\hline Acanthiza pusilla & foliage searcher & 55 & 32 & 64 & 70 \\
\hline Chrysococcyx lucidis & foliage searcher & 1 & 0 & 0 & 2 \\
\hline Pardalotus punctatus & foliage searcher & 2 & 4 & 4 & 6 \\
\hline Pardalotus striatus & foliage searcher & 4 & 2 & 0 & 15 \\
\hline Acanthiza lineate & foliage searcher & 4 & 19 & 10 & 2 \\
\hline Melithreptus lunatus & foliage searcher & 2 & 20 & 0 & 32 \\
\hline Lichenostomus chrysops & foliage searcher & 43 & 52 & 34 & 78 \\
\hline Acanthorhynchus tenuirostris & nectarivore & 0 & 5 & 2 & 16 \\
\hline Philemon corniculatus & nectarivore & 0 & 4 & 0 & 2 \\
\hline Anthochaera carunculata & nectarivore & 1 & 10 & 2 & 12 \\
\hline Platycercus elegans & granivore & 25 & 20 & 24 & 36 \\
\hline Cacatua roseicapilla & granivore & 0 & 2 & 0 & 0 \\
\hline Callocephalon fimbriatum & granivore & 2 & 0 & 3 & 2 \\
\hline Cacatua galerita & granivore & 33 & 20 & 21 & 45 \\
\hline Leucosarcia melanoleuca & granivore & 0 & 0 & 0 & 1 \\
\hline Corvus coronoides & not classified & 2 & 0 & 0 & 0 \\
\hline Zoothera lunulata & not classified & 1 & 7 & 0 & 2 \\
\hline Turdus merula & not classified & 1 & 1 & 2 & 0 \\
\hline Alisterus scapularis & not classified & 0 & 0 & 1 & 2 \\
\hline Calyptorhynchus funereus & not classified & 0 & 0 & 0 & 5 \\
\hline Total number of individuals & & 324 & 355 & 330 & 499 \\
\hline Total number of species & & 28 & 33 & 28 & 33 \\
\hline
\end{tabular}

\section{References}

Andrén H (1994) Effects of habitat fragmentation on birds and mammals in landscapes with different proportions of suitable habitat: a review. Oikos 71:355-366

Antongiovanni M, Metzger JP (2005) Influence of matrix habitats on the occurrence of insectivorous bird species in Amazonian forest fragments. Biol Conserv 122:441-451

Bentley JM, Catterall CP (1997) The use of bushland, corridors, and linear remnants by birds in southeastern Queensland, Australia. Conserv Biol 11:1173-1189

Bibby CJ, Burgess ND, Hill DA (1992) Bird census techniques. Academic Press, London, UK

Bierregaard Jr RO, Stouffer PC (1997) Understory birds and dynamic habitat mosaics in Amazonian Rainforest. In: Laurance WF, Bierregaard Jr RO (eds) Tropical forest remnants. Ecology, management and conservation of fragmented communities. University of Chicago Press, Chicago, USA, pp 138-155
Brittingham MC, Temple SA (1983) Have cowbirds caused forest songbirds to decline? BioScience 33: $31-35$

Catterall CP, Piper SD, Bunn SE, Arthur JM (2001) Flora and fauna assemblages vary with local topography in a subtropical eucalypt forest. Aust Ecol 26:56-69

Cody ML (1985) Habitat selection in birds. Chicago University Press, Chicago, USA

Darveau M, Beauchesne P, Bélanger L., Huot J, Larue P (1995) Riparian forest strips as habitat for breeding birds in boreal forest. J Wildlife Manage 59:67-78

DeGraaf RM (1992) Effects of even-aged management on forest birds at northern hardwood stand interfaces. For Ecol Manage 46:95-110

Estades CF, Temple SA (1999) Deciduous-forest bird communities in a fragmented landscape dominated by exotic pine plantations. Ecol Appl 9:573-585

Ford HA, Barrett GW, Saunders DA, Recher HF (2001) Why have birds in the woodlands of southern Australia declined? Biol Conserv 77:71-88 
Gascon C, Lovejoy TE, Bierregaard Jr RO, Malcolm JR, Stouffer PC, Vasconcelos HL, Laurance WF, Zimmerman B, Tocher M, Borges S (1999) Matrix habitat and species richness in tropical forest remnants. Biol Conserv 91:223-229

Genstat (2003) Genstat, seventh edition, version 7.2. VSN International Ltd, Hemel Hempstead, UK

Gepp BC (1976) Bird species distribution and habitat diversity in an exotic forest in South Australia. Aust Forest 39:269-287

Hagar JC (1999) Influence of riparian buffer width on bird assemblages in western Oregon. J Wildlife Manage 63:484-496

Hannon SJ, Paszkowski CA, Boutin S, DeGroot J, Macdonald SE, Wheatley M, Eaton BR (2002) Abundance and species composition of amphibians, small mammals, and songbirds in riparian forest buffer strips of varying widths in the boreal mixedwood of Alberta. Can J Forest Res 32:1784-1800

Keast A, Recher HF, Ford H, Saunders D (1985) Birds of eucalypt forests and woodlands: ecology, conservation, management. Surrey Beatty \& Sons Pty Limited, Chipping Norton, Australia

Kikkawa J (1982) Ecological associations of birds and vegetation structure in wet tropical forests of Australia. Aust J Ecol 7:325-345

Kilgo JC, Sargent RA, Chapman BR, Miller KV (1998) Effect of stand width and adjacent habitat on breeding bird communities in bottomland hardwoods. J Wildlife Manage 62:72-83

Lambert JD, Hannon SJ (2000) Short-term effects of timber harvest on abundance, territory characteristics, and pairing success of ovenbirds in riparian buffer strips. Auk 117:687-698

Laurance WF (1990) Comparative responses of five arboreal marsupials to tropical forest fragmentation. J Mammal 71:641-653

Laurance WF (1991) Ecological correlates of extinction proneness in Australian tropical rain forest mammals. Conserv Biol 5:79-89

Laurance SGW (2004) Responses of understory rain forest birds to road edges in central Amazonia. Ecol Appl 14:1344-1357

Laurance WF, Bierregaard Jr RO (1997) Tropical forest remnants. Ecology, management and conservation of fragmented communities. University of Chicago Press, Chicago, USA

Lee M, Fahrig L, Freemark K, Currie DJ (2002) Importance of patch scale vs landscape scale on selected forest birds. Oikos 96:110-118

Lindenmayer DB, Cunningham RB, Donnelly CF, Nix HA, Lindenmayer BD (2002) Effects of forest fragmentation on bird assemblages in a novel landscape context. Ecol Monogr 72:1-18

Lindenmayer DB, McIntyre S, Fischer J (2003) Birds in eucalypt and pine forests: landscape alteration and its implications for research models of faunal habitat use. Biol Conserv 110:45-53

Luck GW, Possingham HP, Paton DC (1999) Bird response at inherent and induced edges in the Murray
Mallee, South Australia. 1. Differences in abundance and diversity. Emu 99:157-169

MacNally RC (1990) The roles of floristics and physiognomy in avian community composition. Aust J Ecol 15:321-327

MacNally RC (1994) Habitat-specific guild structure of forest birds in south-eastern Australia - a regionalscale perspective. J Anim Ecol 63:988-1001

Møller AP (1989) Nest site selection across field-woodland ecotones: the effect of nest predation. Oikos 56:240 246

Pearson SF, Manuwal DA (2001) Breeding bird response to riparian buffer width in managed Pacific Northwest Douglas-Fir Forests. Ecol Appl 11:840-853

Piper SD, Catterall CP (2003) A particular case and a general pattern: hyperaggressive behaviour by one species may mediate avifaunal decreases in fragmented Australian forests. Oikos 101:602-614

Price OF, Woinarski JCZ, Robinson D (1999) Very large area requirements for frugivorous birds in monsoon rainforests of the Northern Territory, Australia. Biol Conserv 91:169-180

Pyke GH, Pulliam HR, Charnov EL (1977) Optimal foraging in a selective review of theory and tests. Quart Rev Biol 52:137-154

Recher HF, Kavanagh RP, Shields JM, Lind P (1991) Ecological association of habitats and bird species during the breeding season in southeastern New South Wales. Aust J Ecol 16:337-352

Recher HF, Shields J, Kavanagh RP, Webb G (1987) Retaining remnant mature forest for nature conservation at Eden, New South Wales: a review of theory and practice. In: Saunders DA, Arnold GW, Burbidge AA, Hopkins AJ (eds) Nature conservation: the role of remnants of vegetation. Surrey Beatty and Sons, Chipping Norton, Australia, pp 177-194

Renjifo LM (2001) Effect of natural and anthropogenic landscape matrices on the abundance of subandean bird species. Ecol Appl 11:14-31

Restrepo C, Gómez N (1998) Responses of understory birds to anthropogenic edges in a neotropical montane forest. Ecol Appl 8:170-183

Ricketts TH (2001) The matrix matters: effective isolation in fragmented landscapes. Am Nat 158:87-99

S-PLUS (2003) SPLUS 6.2. Insightfull Corp, Seattle, WA, USA

Sekercioglu CH, Ehrlich PR, Daily GC, Aygen D, Goehring D, Sandi RF (2002) Disappearance of insectivorous birds from tropical forest fragments. Proc Natl Acad Sci 99:263-267

Shirley SM, Smith JNM (2005) Bird community structure across riparian buffer strips of varying width in a coastal temperate forest. Biol Conserv 125:475-489

Sieving KE, Willson MF, de Santo TL (2000) Defining corridor functions for endemic birds in fragmented south-temperate rainforest. Conserv Biol 14:11201132

Sisk TD, Haddad NM, Ehrlich PR (1997) Bird assemblages in patchy woodlands: modelling the effects of edge and matrix habitats. Ecol Appl 7:1170-1180 
Specht RL, Specht A (1999) Australian plant communities. Dynamics of structure, growth and biodiversity. Oxford University Press, Melbourne, Australia

Stauffer DF, Best LB (1980) Habitat selection by birds of riparian communities: evaluating effects of habitat alterations. J Wildlife Manage 44:1-15

Stouffer PC, Bierregaard Jr RO (1995) Use of Amazonian forest fragments by understory insectivorous birds. Ecology 76:2429-2445

Tubelis DP, Cowling A, Donnelly C (2004a) Landscape supplementation in adjacent savannas and its implications for the design of corridors for the conservation of forest bird species in the central Cerrado, Brazil. Biol Conserv 118:353-364

Tubelis DP, Lindenmayer DB, Cowling A (2004b) Novel patch-matrix interactions: patch width influences matrix use by birds. Oikos 107:634-644

Warburton NH (1997) Structure and conservation of forest avifauna in isolated rainforest remnants in tropical
Australia. In: Laurance WF, Bierregaard Jr RO (eds) Tropical forest remnants. Ecology, management and conservation of fragmented communities. University of Chicago Press, Chicago, USA, pp 190-206

Wethered R, Lawes MJ (2003) Matrix effects on bird assemblages in fragmented Afromontane forests in South Africa. Biol Conserv 114:327-340

Wiens JA (1989) The ecology of bird communities. Cambridge University Press, Cambridge, USA

Wilcove DS, McLellan CH, Dobson AP (1986) Habitat fragmentation in the temperate zone. In: Soulé ME (ed) Conservation biology. The science of scarcity and diversity. Sinauer Associates, Sunderland, MA, USA, pp 237-256

Zanette L, Doyle P, Trémont SM (2000) Food shortage in small fragments: evidence from an area-sensitive passerine. Ecology 81:1654-1666 